\title{
Percepções e Imagens na Política Externa do Estado Novo Português: A Importância do Triângulo Identitário
}

\author{
Pedro Emanuel Mendes \\ Investigador do Instituto Português de Relações Internacionais da Universidade Nova de Lisboa (IPRI) e \\ Professor na Faculdade de Economia da Universidade de Coimbra (FEUC). Portugal. \\ E-mail: pemanuelmendes@gmail.com ORCID: https://orcid.org/0000-0002-6321-8344
}

\section{INTRODUÇÃO}

— ste artigo propõe uma teorização sobre a construção das ideias e Estado Novo português. Conjuga argumentos teóricos clássicos da Análise da Política Externa (APE) ligados às abordagens fenomenológicas (Mendes, 2020a) - "images" (Boulding, 1959), "belief systems" (Holsti, 1962), "perceptions" (Jervis, 2017) - com argumentos construtivistas sobre a importância da história, da identidade e da cultura política na construção dos interesses e decisões da política externa dos Estados (Katzentsein, 1996; Kubalkova, 2001; Houghton, 2007; Checkel, 2008; Kowert, 2010; Onuf, 2013; Mendes, 2016, 2017a). O artigo demonstra que os Estados não decidem apenas com base numa lógica racional (utilitária e consequencialista). Embora os Estados assumam argumentos racionais, as suas decisões são, em primeiro plano, fruto de processos de construção social e ideacional (Mendes, 2018). Ao contrário das explicações racionalistas tradicionais, o artigo sublinha que, para além da lógica racional, é essencial assumir uma precedente lógica identitária para explicarmos as opções de política externa dos Estados. Esta lógica identitária é especialmente importante em processos de transição política que implicam reconstruções identitárias e ideológicas nacionalistas, como aconteceu com o Estado Novo.

Outra dimensão importante para compreendermos a lógica identitária da política externa dos Estados é a sua relação com a história e com a formação dos seus consequentes padrões históricos (Mendes, 2017b). O peso da história conta e é importante na construção social das 
doutrinas e imagens das elites decisoras. Não podemos compreender as interpretações, imagens e percepções especiais da política externa portuguesa sem considerarmos a sua história imperial.

Neste quadro, importa recordar que Portugal foi o primeiro império multicontinental da Era Moderna e construiu um importante padrão histórico global na sua política externa, o que lhe conferiu uma grande projeção internacional. Comparativamente com outros Estados da sua dimensão, Portugal teve um papel importante nas relações internacionais e chegou mesmo a ser uma das principais potências mundiais, nos séculos XV e XVI (Modelski, 2000). Essa qualidade internacional do Estado português sempre se assumiu como uma parte essencial da sua identidade e interesse nacional.

A partir do século XVII, Portugal começa a desenvolver um normal declínio, interno e externo, agravado pela União Ibérica. No século XIX, esse declínio teve como marcos principais as invasões francesas, a perda da soberania metropolitana e a redução da sua soberania imperial, com a independência do Brasil. Em seguida, Portugal tentou reconstruir a sua vocação imperial na África, mas novamente se deparou com obstáculos, designadamente a negação das suas pretensões na Conferência de Berlim, em 1890, e o resultante ultimato britânico, que impuseram a Portugal a sua condição de pequeno poder e traumatizaram o prestígio internacional português.

Na primeira metade do século $X X$, Portugal experienciou duas importantes transições políticas internas, da Monarquia para a República e desta para o Estado Novo. Essas transições, para além de outros importantes aspectos, também foram influenciadas pela ideia da restauração do prestígio internacional e do "génio português". Nesse contexto, durante o Estado Novo existiu uma preocupação em construir uma ordem nova nacionalista que, de algum modo, resgatasse Portugal do seu declínio e permitisse ao Estado português desempenhar um papel especial no mundo. Aquilo que, como veremos, várias das suas elites designavam como a "missão" ou a "finalidade histórica" de Portugal.

Recorrendo a uma análise dos discursos, declarações e ensaios das elites portuguesas, este artigo apresenta uma contextualização das ideias e doutrinas da lógica identitária que justificou as opções da política externa do Estado Novo salazarista. O seu objetivo é demonstrar que 
as decisões da política externa de Portugal neste período se explicam, acima de tudo, pela construção social e intersubjetiva de um triângulo identitário que formatou as percepções e imagens dos seus líderes.

$\mathrm{O}$ artigo centra-se na análise das percepções e imagens nacionais ${ }^{1}$ das elites que guiaram as estratégias da política externa do Estado Novo face aos desafios colocados à inserção internacional de Portugal como Estado simultaneamente europeu e imperial. Identifica a inserção internacional de Portugal na construção da ordem internacional no pós-Segunda Guerra Mundial e as respostas da política externa portuguesa face a dois desafios internacionais nas décadas de 1950 e 1960: a integração europeia (CEE) e o movimento anticolonial. Explica as ideias e contextos que originaram o ocidentalismo e o especialismo nacionalista e imperial do Estado Novo, bem como a sua doutrina de resistência face às pressões anticoloniais. Nesse quadro, colocam-se as seguintes questões:

- Quais as percepções dos líderes e elites políticas do Estado Novo salazarista face à integração europeia?

- E quais as principais imagens nacionais e doutrinas da política externa portuguesa nesse período?

O artigo está organizado em três partes. Na primeira, apresenta um enquadramento da política externa do Estado Novo no pós-guerra e faz uma análise das ideias e argumentos das suas elites decisoras face ao início do processo de integração da Europa Comunitária. Na segunda, explica a construção social das imagens do ocidentalismo e especialismo e demonstra a relação entre as percepções e imagens nacionais dos líderes do Estado Novo e a legitimação da doutrina de resistência imperial da política externa portuguesa. Na terceira, desenvolve uma análise crítica dos interesses e desejos da política imperial portuguesa e apresenta uma explicação identitária que ajuda a clarificar a incapacidade da política externa do Estado Novo se adaptar aos desafios pós-imperiais.

$\mathrm{O}$ artigo sublinha que para compreendermos os interesses nacionais dos Estados temos de ter em conta a sua conjuntura histórica e consequente construção identitária. Para contarmos melhores histórias sobre a política externa dos Estados devemos analisar, de forma interligada, a lógica racional dos interesses geopolíticos e a lógica identitária da 
cultura política dos regimes e respectivas construções ideacionais das suas doutrinas de política externa. O principal argumento deste artigo é que não é possível compreender as opções da política externa do Estado Novo sem reconhecer a importância decisiva da construção ideacional dos interesses e preferências das suas elites, nomeadamente da socialização de um triângulo identitário que refletia a identidade e a cultura política do regime autoritário português.

\section{PERCEPÇÕES E IMAGENS NACIONAIS DO ESTADO NOVO NA NOVA ORDEM EUROPEIA PÓS-1945: O NACIONALISMO IMPERIAL E ANTIFEDERALISTA}

Com o fim da Segunda Guerra Mundial e o início da nova ordem internacional, Portugal acusa algumas dificuldades para se adaptar à situação. Embora não sofra a ostracização que sofreu a Espanha, a percepção do governo português face às transformações que estruturam a nova ordem internacional é pessimista e defensiva (Ferreira, 1993; Telo, 1995; Rollo, 1998). A nova hierarquia de poderes no sistema internacional é percepcionada por Oliveira Salazar como um recuo do (seu) ocidente cristão, conservador, nacionalista e imperial. Apesar disso, Salazar não encontra razões para alterar as diretrizes imperiais e atlânticas da política externa portuguesa. Na sua ótica:

\footnotetext{
Os "chamados acordos regionais", cuja admissibilidade as realidades presentes aconselham, ressalvarão para nós, e em primeiro lugar, como o instrumento de mais vasto alcance, a aliança inglesa e permitirão o desenvolvimento das relações, já tão estreitas, com os Estados Unidos, a França e os nossos vizinhos coloniais, a política peninsular e esta íntima ligação com o Brasil, que não está escrita em tratados, por viver do sangue dos dois povos. Enraizados aqui e em África, em largas costas do Atlântico, para onde, por fatalidade das circunstâncias, se vai mudar o centro da gravidade da política do Ocidente, temos bem garantido o nosso lugar. (Salazar, 1951:112-113).
}

No início do Pós-Guerra, a política externa portuguesa assenta na exploração complementar de três vetores principais: o vetor atlântico (a norte, o Reino Unido e os EUA; a sul, o Brasil), o vetor peninsular (Espanha) e o estruturante vetor imperial. Este subsumia a grande linha de força geopolítica da política externa de Salazar, o atlantismo imperial e a neutralidade continental. Nesse quadro, Portugal não deveria se desviar dos fundamentos da sua política externa tradicional assente na "liberdade e segurança no Atlântico" (Salazar, 1951:413). Salazar sublinha os inconvenientes de uma alteração da estratégia atlântica e ultramarina de Portugal: 
Esta prudente orientação foi umas tantas vezes interrompida ou alterada pela intervenção portuguesa nos conflitos internos da Europa. Sempre que o fizemos, livremente ou compelidos por outros e pelas circunstâncias, distraímo-nos prejudicialmente das nossas tarefas ultramarinas, e sem lucros, antes com graves danos e perdas de vidas e de fazenda, voltámos para a Pátria, se às vezes com glória, sempre desiludidos das nossas intervenções. Através da história, estes desvios da linha mestra que é definida pelas necessidades vitais do povo português - face ao mar, costas à terra não constituem precedentes a seguir, mas a evitar na medida do possível (Salazar, 1951:413-414; ênfases do autor).

Portugal tinha uma doutrina fundamentalmente atlântica, imperial, soberanista, bilateral e não acreditava nas virtualidades de movimentos políticos supranacionais, nem na institucionalização de acordos de cooperação regional e multilateral na Europa. Essa ideia defendida pelo chefe do governo, era partilhada pela maioria das elites portuguesas da época. Para além do desinteresse de Portugal relativamente à ideia da integração europeia, "existia mesmo uma marcada hostilidade e até descrença acerca da viabilidade de quaisquer projetos nesse sentido" (Magalhães, 1987-1988:51). Salazar defendia uma atitude prudente e soberanista contra experiências que questionassem o seu "nacionalismo, construtivo sem agressividade, colaborante sem exclusivismos, mas enraizado na terra e nas almas" (Salazar, 1959:320). Na sua ótica, seria a continuidade desse nacionalismo "a revelar-se a melhor defesa contra experiências ousadas, de que infelizmente se não haveria de avaliar os benefícios possíveis senão depois de sofridas as desvantagens reais" (Salazar, 1959:320).

Nesse período, existiu uma rejeição natural face aos movimentos de cooperação internacional de caráter supranacional que possibilitaram questionar a doutrina nacionalista do Estado Novo. O chefe do governo português é peremptório:

Esse vago pensamento começa já a revestir aqui e além formas jurídicas conhecidas, como a de federação ou confederação. Se ao meu espírito é suficientemente nítida a razão por que alguns Estados defendem para o Ocidente europeu tais formas de integração, não consegui ainda descortinar os motivos que impelem outros a aceitar, senão a bendizer, esta sorte de liquidação nacional. (Salazar, 1959:319) 
Essa exaltação nacionalista é uma das características básicas da construção do Estado Novo. A começar no seu líder e a acabar nas elites políticas e diplomáticas, todos, em regra, têm uma percepção nacionalista e crítica do movimento europeu de cooperação supranacional ${ }^{2}$.

Portugal formata uma doutrina de política externa relativamente antieuropeísta que pressupõe uma estratégia de rejeição e uma atitude de permanente ceticismo em relação ao movimento de integração europeia. De forma clara, Salazar afirma:

[...] da Europa nada nos interessa substancialmente no terreno político: Interessam-nos mais Angola e Moçambique, e até o Brasil. [...] A nossa feição atlântica impõe-nos, pois, limites à colaboração europeia (MNE, 1953).

O líder do Estado Novo tem uma percepção negativa face às ideias federalistas do movimento de cooperação europeu, pois elas esbarram contra os seus princípios nacionalistas, imperiais e autoritários e, consequentemente, contra a imagem essencialista ${ }^{3}$ de Portugal. Em sua opinião: "a federação europeia, como pretende constituir-se, suscita mais problemas do que os resolve" (MNE, 1953).

Para Salazar, uma coisa eram os interesses da Europa para lá dos Pireneus, outra, bastante diferente, eram os interesses dos Estados da Península Ibérica. O líder português defendia ser mais natural uma eventual coordenação entre Portugal, Brasil, Espanha e a América Latina "num grande bloco ibero-americano", à imagem da Comunidade Britânica, ainda que sem o seu "grau de estruturação constitucional", do que a Península ser "absorvida ou decisivamente influenciada pelo peso da nova organização" europeia (MNE, 1953). A sua conclusão é que:

Nestas circunstâncias, a questão da federação que se pretende fazer nascer no centro e ocidente da Europa não nos interessa senão na dupla medida em que pode diminuir a capacidade de defesa europeia e em que, pretendendo alargar-se para além dos limites primários, nos embarace ou impeça de seguir o nosso caminho (MNE, 1953).

Essa visão foi igualmente expressa pelo seu pelo ministro dos Negócios Estrangeiros, Paulo Cunha, em entrevista ao jornal alemão Diplomatische Korrespondenz. Questionado sobre a atitude de Portugal em relação ao movimento de integração europeia, o ministro português, de forma diplomática, mas clara, afirma: 
Acompanhamos esse movimento com todo o interesse, e colaboramos com a melhor vontade em todos os esforços para se intensificar a coordenação entre as Nações ocidentais. Mas abstemo-nos de quanto respeita a formas de integração ou fusão, com a criação de organismos supranacionais. Na verdade, a nossa situação especial acarreta consigo que estejamos mais dirigidos para o oceano, para o mundo atlântico, do que para o interior do nosso continente. [...] Portugal é um Império Ultramarino, e dentro do interesse que têm para nós essas Províncias Ultramarinas, lógico é que não manifestemos pela unificação europeia um interesse tão grande com os países da Europa Central (MNE, PC; ênfases do autor).

Nas décadas de 1940 e de 1950, Portugal não tinha como objetivo preferencial da sua política externa desenvolver uma relação com a Europa Comunitária. Para além da tradicional aliança marítima com a Inglaterra, o país tinha relações bilaterais tradicionais com os principais Estados europeus, mas não acreditava na organização federal europeia. Os decisores portugueses da época definiram que não era do interesse nacional uma aproximação ao movimento democrático da integração europeia (Mendes, 2012).

\section{O OCIDENTALISMO E O ESPECIALISMO DA POLÍTICA EXTERNA DO ESTADO NOVO}

Para Portugal, a Europa era sobretudo um espaço geopolítico e cultural que se integrava numa importante imagem nacional: o ocidentalismo. Sinteticamente, o ocidentalismo português baseava-se na necessidade da Europa de se enquadrar na "formação de um bloco defensivo euro-americano, que procurasse levantar uma barreira ao avanço do Imperialismo Soviético" (Melo, 1965:11).

Embora com raízes na leitura heroica da missão especial - civilizadora cristã - dos Descobrimentos, a imagem ocidentalista ganha uma nova reformulação política face à necessidade de posicionar Portugal perante o conflito da Guerra Fria. Nesse quadro, a participação de Portugal na fundação da Organização do Tratado do Atlântico Norte (OTAN) também se explica pela cultura política ocidentalista anticomunista do Estado Novo e pela percepção dos seus decisores relativamente à necessidade de contenção do comunismo anticristão. Por isso, Oliveira Salazar salienta a relevância da OTAN na arquitetura ocidentalista da política externa portuguesa. Nas suas palavras: "o Pacto Atlântico ficará registrado na história como o símbolo e a expressão de uma 
nova cruzada: a defesa da civilização ocidental e cristã. País ocidental e católico por excelência, Portugal deve acolhê-lo e ratificá-lo com sincero entusiasmo" (Salazar, 1951:405; ênfases nossas).

As principais imagens nacionais que irão influenciar as opções e doutrinas da política externa de Portugal nesse período são o ocidentalismo, o imperialismo atlântico e o antifederalismo europeu. Este antifederalismo, para além de dever ser compreendido à luz da dicotomia europeia relativa aos regimes demoliberais versus regimes autoritários, deve ser explicado, antes de tudo, pela percepção das elites políticas portuguesas face à Europa. Essa percepção defendia que a aproximação à Europa Comunitária prejudicaria a verdadeira e fundamental opção da política externa de Portugal: o império ${ }^{4}$.

As seguintes afirmações do chefe do governo português são ilustradoras da sua visão ocidentalista e imperial:

Se posso ser intérprete do povo português, devo afirmar que é tão entranhado o seu amor à independência e aos seus territórios ultramarinos, como parte relevante e essencial da sua história, que a ideia de federação, com prejuízo de uma e outros, lhe repugna absolutamente. Precisamos, aliás, ter presente que o Ultramar lhe tem interessado sempre mais que a Europa continental: raras vezes Portugal interveio nos seus dissídios e sempre que o fez foi com prejuízo de outros interesses mais altos. A expansão ultramarina - descobrir, missionar, fazer nações além-mar, como no Brasil - é o traço mais saliente da sua história, é decididamente a sua vocação. Se no Pacto Atlântico nos comprometemos a auxiliar as outras nações da Europa com todas as nossas forças, em caso de ataque do imperialismo russo, é que há a compreensão nítida de que esse imperialismo traz consigo os elementos destrutivos da nossa mesma razão de ser, de forma que evitar o ataque pela organização ou vencê-lo pela força é condição necessária ao prosseguimento da nossa missão no mundo. Mas além disto - o que é no fundo a paz, a liberdade, o génio e o espírito da civilização cristã da Europa -, da Europa nada mais nos interessa. (MNE, 1953)

As elites do Estado Novo aderiram ao discurso do seu líder. Esse discurso apresentava Portugal como um Estado que tinha a missão de defender os valores cristãos e ocidentais. Tal como no passado, no combate ao "infiel islâmico", também agora, no século XX, Portugal tinha a missão de combater o "infiel comunista". Essa ideia de "missão ocidentalista" foi incorporada pela leitura histórica, nacionalista e 
heroica do Estado Novo e passou a fazer parte do imaginário político português. A generalidade das elites assumiu tal discurso e os decisores da política externa portuguesa adaptaram-no às suas conveniências e preferências políticas. Em primeiro lugar, através de uma aproximação aos EUA e à OTAN. Em segundo lugar, e interligadamente, na argumentação justificativa do papel de Portugal na defesa do ocidente em África. Uma das principais justificações políticas da defesa das províncias ultramarinas portuguesas foi a contenção da expansão do comunismo e a manutenção dos territórios africanos como baluartes de defesa dos valores ocidentais e cristãos.

A imagem nacional ocidentalista foi um dos fatores ideacionais que fundamentou a doutrina de resistência ${ }^{5}$ da política externa portuguesa face ao litígio entre Portugal e a Organização das Nações Unidas (ONU) relativamente aos processos de descolonização. O ocidentalismo, juntamente com o especialismo da colonização portuguesa, foram os principais argumentos políticos utilizados por Portugal na sustentação da sua política externa de resistência face ao movimento anticolonial.

Existiu ainda um argumento jurídico, uma emanação dos políticos, que teve origem na revisão constitucional de 1951. Nesse momento, através de uma operação política muito típica do Estado Novo, a reformulação jurídica, o Ato Colonial de 1930 é integrado na Constituição da República Portuguesa e as palavras "colônias" e "império colonial" são eliminadas e substituídas por "províncias ultramarinas" e "ultramar". Essa importante reformulação jurídica pretendia atenuar a pressão política internacional que se adivinhava face à crescente globalização da Guerra Fria em que, no quadro da competição bipolar para ganhar espaços de influência, ambas as superpotências (EUA e URSS) defendiam a descolonização. Como Maxwell (1985:531) sublinha é importante compreender as várias "interrelações formais e informais" entre a África portuguesa, o contexto global e ocidental de contenção do comunismo e o contexto regional de "libertação" africana. Tanto Maxwell (1985:2005) como MacQueen (1998:76) sublinham a dimensão internacional do "problema africano de Portugal"6.

Historicamente, Portugal sempre desenvolveu argumentos de defesa dos seus interesses internacionais com fundamentações jurídicas. Essa é uma tradição que remonta à "polémica da liberdade dos mares" 
(Caetano, 1971:9). Portugal sempre tentou construir argumentações jurídicas que pudessem suportar os seus objetivos políticos e contrariar a política de imposição de poder de potências mais poderosas ${ }^{7}$.

Nesse quadro, com a reformulação jurídica operada na revisão constitucional de 1951, Portugal deixa de ter colônias e passa a ter províncias ultramarinas. Essa transição semântico-jurídica vai ser um importante argumento utilizado por Portugal. $\mathrm{O}$ argumento permitia que, por exemplo, em dezembro de 1956, a propósito da questão goesa, o representante diplomático de Portugal na Assembleia Geral da ONU afirmasse que não existia colonialismo em Goa. Política e legalmente, Goa não era uma colônia, mas sim uma província ultramarina que fazia parte do Estado pluricontinental português (MNE, 1970).

O especialismo português não era só relativo à colonização. O especialismo tinha três dimensões principais: a histórica, a antropológica e a geopolítica. Essas dimensões estavam interligadas e resultaram na construção de uma metafísica identitária, imperial-essencialista, que formatava as percepções e imagens nacionais dos decisores da política externa portuguesa.

A dimensão histórica do especialismo português traduzia-se na interiorização de uma interpretação nacionalista da forma universalista de Portugal estar no mundo, iniciada com o movimento marítimo das descobertas. Embora partisse das ideias relativas à colonização missionária tendencialmente benigna e assente na miscigenação, o especialismo histórico português fundamentava-se na singular disseminação global de Portugal e na consequente projeção extraeuropeia dos seus interesses.

Como sublinhou Adriano Moreira (1966:9), Portugal foi o primeiro império ocidental e o precursor do processo de planetização das relações internacionais iniciado com a primeira viagem de circum-navegação liderada por Fernão Magalhães ${ }^{8}$. Essa tradição histórica foi especialmente reconstruída e apropriada pelas ideias e ideologias de exaltação nacionalista do Estado Novo ${ }^{9}$. As suas elites vão construir um discurso sobre uma imagem nacional, pluricontinental e especial. Essa imagem articulava um conjunto de ideias, especiais, relativas à missão histórica de Portugal ${ }^{10}$. Ideias que construíam discursos e práticas sobre o especialismo da finalidade de Portugal no mundo e que foram exemplarmente captados nas palavras de Henrique Galvão ${ }^{11}$ : 
Para Portugal, as colônias são exatamente as determinantes da sua finalidade internacional - finalidade que corresponde à sua história (...) a História de Portugal reflete sucessivamente, com a formação do Reino, uma finalidade Peninsular; com a luta contra os Mouros, o elemento antieuropeu, luta que é nitidamente uma defesa da Europa, uma finalidade europeia; finalmente, na expansão dos nossos domínios ultramarinos, uma finalidade Mundial (Galvão, 1930:5) ${ }^{12}$.

A dimensão antropológica traduzia-se, por comparação com os colonialismos hegemônicos tradicionais, numa diplomacia tradicionalmente mais comercial do que conquistadora, na boa capacidade de relacionamento intercultural com povos e culturas diferentes e, sobretudo, na especial capacidade de Portugal praticar a miscigenação ${ }^{13}$. Essas características contribuíram para a negação de fórmulas institucionais de apartheid e para a invenção de sociedades relativamente multirraciais, cujo exemplo maior foi o Brasil ${ }^{14}$.

Essa dimensão ganhou um particular significado com o aproveitamento político do lusotropicalismo de Gilberto Freyre ${ }^{15}$. Em meados da década de 1950, com a entrada de Portugal na ONU e a pressão dos movimentos anticoloniais, Portugal encontrou no lusotropicalismo a justificação científica ideal para os seus argumentos políticos. O Estado Novo passou a adotar um discurso oficial lusotropical como instrumento de propaganda e de legitimação da sua política externa imperial.

Existiram três formas principais de apropriação do pensamento de Freyre pelo Estado Novo (Castelo, 1988; Léonard, 1997). A primeira foi a adoção de uma versão simplificada e nacionalista do lusotropicalismo como discurso oficial externo. A segunda foi a penetração do lusotropicalismo no meio acadêmico e na formação científica dos quadros da administração ultramarina ${ }^{16}$. Finalmente, existiu um discurso oficial interno - metropolitano e ultramarino - no qual se procurou formatar uma ideologia de suporte à benignidade da colonização lusotropical e "do modo português de estar no mundo"17. Com o lusotropicalismo, o Estado Novo encontrou uma racionalização científica que legitimava o especialismo multicultural e multirracial do império português.

De acordo com Freyre, Portugal é um caso especial que conseguiu ter sucesso no desenvolvimento de uma "civilização lusotropical" nos seus territórios ultramarinos (Freyre, 1958). Essa visão foi adotada por vários setores das elites portuguesas, nomeadamente pelo sofisticado 
e, por vezes, eminência parda do pensamento internacional português, Adriano Moreira. Claramente influenciado pelo contexto da época, nomeadamente sobre a necessidade de dar uma resposta ao terceiro-mundismo anticolonial saído de Bandung, Moreira desenvolveu uma tese, mais política que acadêmica, sobre o papel especial do colonialismo português, que caracterizou como "colonialismo missionário" (Moreira, 1955a, 1955b, 1956, 1957).

Na sua ótica, os discursos anticoloniais de Bandung não tinham em consideração o caráter não racista da "missão civilizadora do colonialismo português" (Moreira, 1955a:15). O colonialismo português era a prova que era possível aos povos europeus e africanos viverem de forma harmoniosa e pacífica. Desse modo, Portugal tinha condições únicas para liderar um movimento de "reabilitação do colonialismo" que promovesse uma "ética anticolonial" com base nos princípios da "igualdade da humanidade" e na garantia da "solidariedade da Europa com África" (Moreira, 1955a:15).

Finalmente, existiu uma dimensão geopolítica. Várias elites militares desenvolvem um pensamento estratégico que integrou as imagens nacionais do triângulo identitário português ${ }^{18}$. A dimensão geopolítica do especialismo português produziu um discurso e uma doutrina geopolítica que contribuiu igualmente para legitimar as opções da política externa portuguesa. No mundo incerto e competitivo da Guerra Fria, Portugal conjugava estabilidade e ordem política, metropolitana e ultramarina, a uma localização estratégica, atlântica e de interligação oceânica, ímpar. Portugal desempenhava um papel "vital" e "incontestável" na defesa do "Mundo Livre" (Comprido, 1956:229-230).

Num esforço de síntese, podemos avançar quatro pontos principais relativamente à influência geopolítica que as imagens nacionais do ocidentalismo e do especialismo tiveram na complexa articulação dos interesses nacionais portugueses com o interesse global da defesa ocidental do "Mundo Livre".

Primeiro, Portugal representava uma importante barreira ideológica (nacionalista, cristã e conservadora) ao avanço do Comunismo. Segundo, a especial tradição atlântica de Portugal proporcionava várias e importantes triangulações estratégicas atlânticas. Isto fazia de Portugal um Estado pivô do "oceano da civilização ocidental", com capacidades para desempenhar um papel central na defesa dos interesses 
da OTAN ${ }^{19}$. Terceiro, Portugal tinha condições únicas de potenciar a relação Europa-África na defesa do mundo ocidental, quer de um ponto de vista da exploração dos seus recursos naturais, quer do ponto de vista da utilização de recursos humanos militares em África. Quarto, Portugal desfrutava de uma sombra geoestratégica distribuída por três oceanos - Atlântico, Índico e Pacífico - com uma extensão territorial de $2.171 .733 \mathrm{~km}^{2}$, espalhados pela Europa (4,2\%), África (94\%), Ásia Índia portuguesa (Goa, Damão e Diu) e Extremo Oriente (Macau) - e Oceania (Timor) (Comprido, 1956).

\section{INTERESSES, IDEIAS E DESEJOS DA POLÍTICA EXTERNA DE RESISTÊNCIA IMPERIAL}

O ocidentalismo e o especialismo foram as imagens nacionais que estruturaram as orientações da política externa portuguesa do Estado Novo nesse período. O ocidentalismo foi, em termos gerais, uma imagem nacional relativamente bem aceita, particularmente pelos aliados de Portugal ${ }^{20}$. Já o especialismo teve mais dificuldades, sobretudo a partir de meados da década de 1950 e particularmente com a ascensão dos movimentos anticoloniais da década de 1960.

Da década de 1960 em diante, as ideias de pluricontinentalidade e multirracialidade, apoiadas na imagem nacional essencialista defensora de que Portugal, para além de existir na Europa, também existia na África, na Ásia e na Oceania - o Portugal do Minho a Timor -, começaram a ser extremamente difíceis de compreender ${ }^{21}$. Sobretudo a partir daqui, numa visão relativamente estática e irrealmente otimista do seu especialismo, Portugal não conseguiu desenvolver uma política que acomodasse as tensões anticoloniais. Depois veio a guerra, e o fim do império era uma questão de tempo.

Todos os Estados, mesmo os europeus detentores de impérios, tinham constatado a inelutável força histórica do movimento descolonizador. Ao contrário, Portugal, em conflito com as Nações Unidas, encontra-se desajustado com o Zeitgeist do sistema internacional.

Embora corajosamente resiliente, a política externa de resistência imperial portuguesa, fazia lembrar a história de Canute, um famoso rei da Inglaterra de origem dinamarquesa que, nos inícios do século XVII, ordenou às ondas do mar que se retirassem, mas - sem surpresa dos 
que o rodeavam - ficou desapontado com a sua ordem. Da mesma forma, Salazar, afirmava que a política imperial portuguesa estava correta. Na sua ótica, "não somos nós que temos de desviar-nos do caminho; são os outros que, em seu próprio interesse, deverão tomá-lo" (Salazar, 1963:8).

Do mesmo modo, o último ministro dos Negócios Estrangeiros de Salazar, Franco Nogueira, sempre assumiu que Portugal estava certo na sua defesa intransigente do Ultramar (Nogueira, 1967, 1979a, 1980, $1984,1985)^{22}$. Independentemente da qualificação de certo ou errado - muito difícil de assegurar na política e na história -, e mesmo da interpretação, aqui assumida, de que a política externa de resistência foi um erro, relevante é compreender a importância e o papel que as percepções e imagens nacionais tiveram nesse período.

A argumentação política e ideacional do especialismo multicultural português não era completamente desajustada de sentido. Na lógica racional e geopolítica de defesa dos interesses portugueses da época, era normal uma postura de protelamento diplomático e jurídico face à pressão da $\mathrm{ONU}$ relativa ao artigo 73 da sua Carta. Numa lógica racional de maximização dos interesses do Estado português, era perfeitamente expectável que isso acontecesse, como aliás, ainda que por formas diversas, sucedeu com outros impérios europeus. Por outro lado, convém não esquecer o estrutural trauma de perda colonial que existia em Portugal. Esse trauma era alimentado por uma narrativa tradicional, sustentada em fatos históricos, sobre a ambição constante de potências mais fortes tentarem usurpar as possessões ultramarinas portuguesas ${ }^{23}$.

Todo esse contexto histórico e ideacional tem de ser levado em consideração para uma explicação, com pressupostos de rigor analítico, sobre a inserção internacional portuguesa durante o Estado Novo. Desse modo, as ideias, umas mais felizes e genuínas, outras, na sua maioria, mais infelizes e mistificadoras, sobre a possibilidade de Portugal construir uma entidade política multirracial e multicontinental, poderiam ter validade diplomática tática, mas não tinham um substrato estratégico real.

Ao contrário do que supunham e acreditavam as elites conservadoras, integracionistas e autoritárias do Estado Novo, a solução mítica lusotropical, a funcionar, só poderia ter acontecido num quadro democrático, quer metropolitano, quer ultramarino. Nessa hipótese contrafatual, 
numa lógica de wishful thinking e de eficiência histórica para os interesses portugueses na África, Portugal deveria ter tido um papel verdadeiro e especial de construção de sociedades multirraciais, o que não aconteceu.

A acontecer, essa solução ideal deveria ter sido acompanhada por um processo de democratização. Hipoteticamente, é possível imaginar que Portugal poderia ter desenvolvido um processo de democratização na década de 1950, que seria exportável para as colônias ${ }^{24}$. Essa democratização teria construído ideias e práticas políticas, que possibilitariam o desenvolvimento de sociedades lusotropicais na África. Um Portugal europeísta e democrático teria proporcionado uma inserção internacional alternativa. Por exemplo, Portugal poderia ter, verdadeiramente, integrado o plano Marshall e a sua visão política de construir sociedades demoliberais desenvolvidas. Nesse quadro, também poderia ter tido a oportunidade de fazer parte da Europa Comunitária, logo em $1957^{25}$. Nesse cenário virtual, Portugal teria realizado mais cedo o seu processo de normalização interna e externa e não teria desperdiçado duas ou três décadas. Poderia ter ganhado muito tempo de paz e desenvolvimento. Mas, como todos sabemos, se existe uma lei histórica incontestável é que a história do mundo não se processa como seria desejável, e a história contemporânea de Portugal e das suas antigas colônias africanas são disso um claro exemplo.

Contudo, não podemos ignorar que várias das elites portuguesas reconheciam o problema e até apontavam a solução, mas sempre num quadro especial de um pretenso imperialismo benigno e multicontinental português. Por exemplo, o embaixador Hall Themido é claro quando afirma:

Como não podemos deixar de estar em África, só a formação de sociedades luso-locais de aculturação portuguesa bem arreigada poderá convencer as forças do continente e os afro-asiáticos, passada a atual fase de exaltação, da natureza especial da nossa colonização, da concepção adotada quanto ao termo desta e, consequentemente, da existência de um país simultaneamente europeu e extra-europeu (Themido, 1960:93).

A principal dificuldade dessa solução, de "formação de sociedades luso-locais", é que tal criação social não se poderia realizar exatamente por decreto ou rapidamente e em força a partir da década de 1960, como alguns pensaram. Uma coisa era um movimento tático, outra um estratégico. Embora seja impossível negar várias e importantes 
exceções do modo não racista e multicultural de Portugal estar no mundo, sobretudo por comparação com outros impérios ocidentais, a verdade é que a regra da colonização portuguesa do Estado Novo não era a de um política consistente e geral de desenvolvimento de sociedades multirraciais em África ${ }^{26}$.

Isso significa que, numa lógica racional, tática, era possível utilizar o especialismo português e interligá-lo com o ocidentalismo para continuar a defender a manutenção dos interesses portugueses em África. Mas não numa lógica identitária, normativa e estratégica. Por quê? Porque a teoria - o especialismo multicultural lusotropical - não correspondia realmente à prática. A ideia de que Portugal poderia construir "novos Brasis" em África pressupunha não ter liquidado o modelo colonial, desenvolvimentista e neofederal de Norton de $\mathrm{Matos}^{27} \mathrm{e}$, sobretudo, ter desenvolvido um processo democrático nas colônias. Numa estratégia política reativa e muito portuguesa, o que aconteceu foi a construção rápida, e com falhas, de uma doutrina especial e aparentemente multirracial que não resistiu à realidade. Mas não só, e não fundamentalmente.

O que fundamentalmente aconteceu foi uma misperception (Jervis, 1976) coletiva dos líderes e elites formuladoras da política externa portuguesa que, inebriadas por imagens nacionalistas e imperiais, acreditaram, mal, que a percepção que tinham era verdadeira. O que é interessante no caso português é que não se tratou, como é comum acontecer, de uma jogada precipitada ou um de erro de cálculo malfeito devido à pressão dos acontecimentos ou à deficiente informação face aos dados do problema ${ }^{28}$.

Essa misperception coletiva, assumida e partilhada intersubjetivamente entre as elites portuguesas do Estado Novo, não foi limitada no tempo, mas antes construída socialmente durante décadas. Essa construção social interligava um conjunto de ideias, imagens, discursos, doutrinas e práticas sobre a inserção internacional de Portugal no mundo e teve por base o que designamos de triângulo identitário. Foi esse triângulo identitário (essencialismo, especialismo e ocidentalismo) que socialmente construiu e legitimou a doutrina de resistência imperial da política externa portuguesa. 
As percepções e imagens das elites do Estado Novo (re)produziram um ambiente político e ideológico que condicionou as ideias e as práticas da política externa portuguesa. Esse ambiente originou um processo de socialização do especialismo imperial português que determinou a misperception coletiva sobre a capacidade de resistência imperial de Portugal. Isto fez com que as elites decisoras tivessem uma predisposição cognitiva que beneficiava uma determinada interpretação da realidade, designadamente a benignidade especial do império português.

As imagens do triângulo identitário do Estado Novo condicionaram a interpretação das elites sobre os acontecimentos da política internacional e limitaram o normal processo de aprendizagem e adaptação racional das suas decisões. Esse caso ajuda a demonstrar que os decisores políticos não agem exatamente numa lógica racional-optimizadora. As opções dos líderes do Estado Novo comprovam que os decisores tendem a escolher a informação e a selecionar os fatos que encaixam nas suas imagens e confirmam as suas ideias. Isso significa que muitas vezes, como aqui se demonstra, os decisores são prisioneiros da sua lógica identitária e das suas consequentes preconcepções (Jervis, 2017; Tetlock, 1999).

Figura 1

Processo de socialização ideacional do triângulo identitário e consequentes percepções das elites do Estado Novo

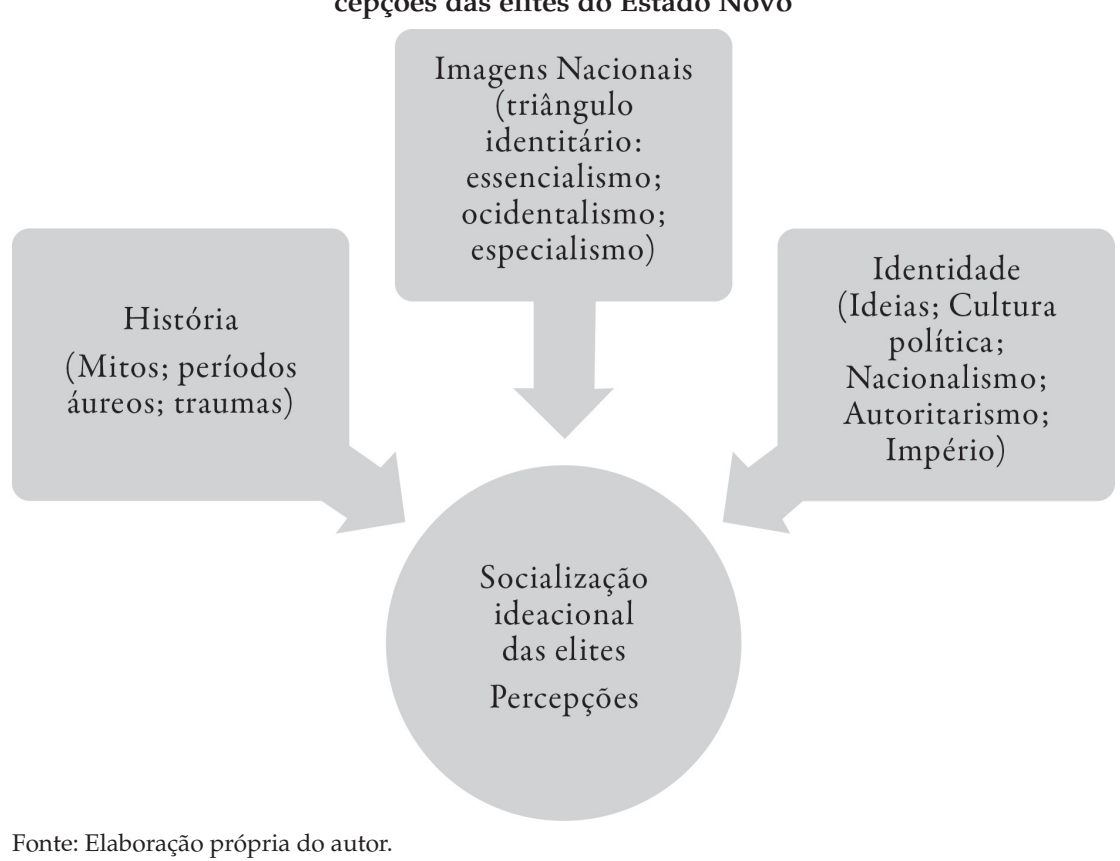


Mais do que as razões racionalistas ligadas às pressões de coligações de interesses internos e aos constrangimentos externos, o que melhor explica a política de resistência imperial é a existência de uma interligação entre o belief system (Holsti,1962; Schafer e Walker, 2006) do Estado Novo e a sua identidade política. Por um lado, este belief system alicerçava a teoria e a prática das políticas públicas. Por outro lado, os líderes do Estado Novo necessitavam da opção imperial para justificar o próprio regime.

Para além dos naturais interesses econômicos e geopolíticos, são as ideias que constroem as identidades e imagens nacionais que formatam e delimitam as opções dos decisores da política externa. No caso do Estado Novo, o fim do império não fazia parte do quadro mental das elites portuguesas. Assim, a descolonização não era uma opção, era um tabu.

Isso não significa que os decisores do Estado Novo não desenvolveram raciocínios racionalistas e não consideraram os custos e benefícios das situações internacionais em análise, nomeadamente a integração europeia e o movimento descolonizador. Ou ainda que, por exemplo, os interesses dos grupos econômicos e das elites (políticas e militares) com interesses no império não tivessem influência na formação das preferências da política externa portuguesa.

O que argumentamos é que existe uma lógica identitária que precede a lógica racional de equação consequencial de custos e benefícios. Sobretudo em regimes autoritários altamente ideológicos, a lógica identitária é constitutiva e determina a construção ontológica dos decisores e das suas visões do mundo (imagens nacionais e internacionais). No processo de formulação das políticas e decisões de política externa, ambas as lógicas de ação - a lógica identitária e a lógica racionalista - estão presentes. Contudo, a lógica identitária é constitutiva e atua num plano pré-condicional, enquanto a lógica racionalista é adaptativa, pois atua num segundo plano em função das condições da situação com as quais os decisores têm de se confrontar e adaptar. Em face da mesma situação internacional, dois decisores com identidades diferentes ativam uma lógica racional semelhante - deliberação utilitária de maximização de custos e minimização dos prejuízos. Todavia, os decisores vão ter interpretações (percepções) diferentes sobre a situação e, embora atuando racionalmente, vão dar valor diferente ao que é 
exatamente um custo e um benefício. Embora ambos pesem os custos e benefícios da situação (lógica racional) as suas percepções e juízos racionais vão variar em função da sua lógica identitária.

Figura 2

Relação entre a lógica identitária e a lógica racional na formulação da política externa dos Estados
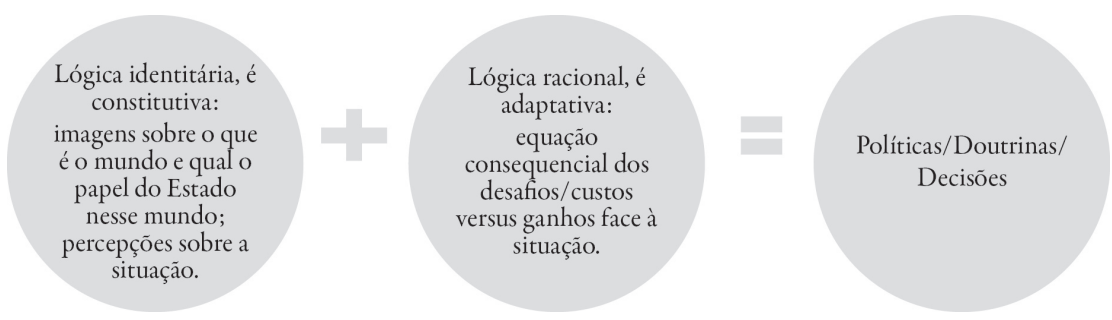

Fonte: Elaboração própria do autor.

É à luz da lógica identitária do Estado Novo e da consequente construção das suas imagens nacionais que devemos compreender a defesa intransigente da política ultramarina de Portugal. Por um lado, o triângulo identitário do essencialismo, do ocidentalismo e do especialismo foi objeto de um processo de construção social que o transformou num discurso ideológico que legitimava as práticas da política externa do regime do Estado Novo. Por outro lado, ele era constitutivo da visão do mundo dos principais decisores que acreditavam na suposta verdade do especialismo, do essencialismo e do ocidentalismo.

Um exemplo útil para a discussão aqui proposta, é analisar uma das raras definições de política externa escritas em Portugal, nomeadamente por um dos principais formuladores da política externa do Estado Novo. Na opinião de Franco Nogueira ${ }^{29}$ :

Uma nação é uma realidade. Uma realidade, antes de tudo para os seus nacionais. Estes têm - ou devem ter - uma visão, uma ideia, um conceito do seu país; [...] têm - ou devem ter - uma sensação quase física da sua pátria, no espaço e no tempo. Um país é um agregado de mistérios e um sistema de certezas íntimas, partilhadas por todos os nacionais. Política externa é fazer projetar, para lá da fronteira, aquela sensação e aquelas certezas. É impor a terceiros a realidade nacional, e defendê-la; é agir de modo a que terceiros a aceitem, acreditem e a vejam como a veem os próprios nacionais. Política externa é o propósito de conseguir que um consenso nacional se transforme num consenso internacional, é afirmar e fazer respeitar a 
tipicidade de um grupo humano diferenciado no conjunto das nações. É por isso que em política externa nunca se chega ao fim: jamais se pode dar por concluído o que quer que seja: é uma luta constante (Nogueira, 1979a: X-XI; ênfases nossas).

Franco Nogueira tem razão ao assumir que a política externa é uma política de identidade e ao salientar que os interesses e as preferências da política externa refletem a identidade política dos Estados. Continua a ter razão, quando sublinha que o sucesso da política externa de um Estado passa por conseguir que os estrangeiros a aceitem como sua. Isto é, que os seus interesses, ideias e práticas sejam consentidos e partilhados pela comunidade internacional.

Não tem razão, porém, Franco Nogueira quando assume uma generalização unitária dos interesses nacionais e tenta naturalizar um consenso objetivo de todos os cidadãos sobre os interesses dos Estados. A política externa dos Estados não é estática, unitária e natural. Embora obedeça a interesses nacionais abstratos relativamente contínuos, a política externa é dinâmica, plural e histórica. Os interesses e preferências que definem a política externa dos Estados são construções sociais, dinâmicas e contingentes, que resultam de contextos políticos e ideacionais particulares e característicos de determinado período histórico.

O problema decisivo é o de saber se os interesses e opções da política externa dos Estados se definem com base em modelos racionalistas, ou se as decisões sobre os interesses nacionais são sempre intersubjetivas e refletem a identidade e a cultura política e institucional em que estão embebidos. Ao contrário da visão tradicional na qual os decisores agem racionalmente em defesa do interesse nacional, importa pensar criticamente sobre a problemática de quem define e por que os interesses nacionais. Nesse quadro, importa problematizar a visão das elites que formularam e contaram histórias sobre a política externa do Estado Novo. Ou seja, é claro que a política externa do Estado Novo foi definida pelos interesses e percepções das elites sobre o que achavam ser "uma visão uma ideia, um conceito do seu país". Contudo, já não é tão claro que as suas opções refletiram um "consenso nacional", "um sistema de certezas íntimas, partilhadas por todos os nacionais" (Nogueira, 1979a; ênfase nossa). 
Esse problema clássico sobre quem decide e por que as opções da política externa é particularmente complexo quando se trata de analisar a política externa de regimes autoritários. Nesses Estados, "todos os nacionais" têm os seus direitos de participação e influência política limitados, mas, por outro lado, existem fortes convicções nacionalistas dos decisores sobre quais são os seus interesses nacionais. Como o caso do Estado Novo revela, nos regimes autoritários nacionalistas a influência da lógica identitária e da consequente construção ideológica das imagens nacionais é decisiva para compreendermos as decisões de política externa, que muitas vezes escapam às análises racionalistas ${ }^{30}$. Na verdade, como aqui se demonstra, e ao contrário do que afirma Nogueira, os interesses dos Estados e as suas políticas externas não são nem unitários nem estáticos, mas, essencialmente, o reflexo das imagens nacionais e dos respectivos interesses e preferências das suas elites decisoras.

\section{CONCLUSÃO}

Não é possível compreender política externa do Estado Novo sem fazer apelo à lógica identitária da ação dos Estados. A lógica identitária é constitutiva e precede a deliberação racional dos decisores sobre determinada situação. O que somos (identidade) e o que pensamos que é o mundo (imagens) determinam as percepções sobre os acontecimentos e as situações internacionais sobre as quais temos de decidir. É a construção ideacional e intersubjetiva da identidade do Estado Novo, designadamente o triângulo identitário do essencialismo, do ocidentalismo e do especialismo, que justifica as razões e os motivos das ideias, práticas e percepções da política externa portuguesa no período analisado (da década de 1940 até a década de 1960).

O líder e as elites políticas do Estado Novo tinham uma percepção pessimista face à Europa Comunitária e não acreditavam no seu sucesso. Salazar defendia um nacionalismo soberanista autárquico que era incompatível com o movimento de integração supranacional da Europa. A sua percepção era a de que a integração europeia contrariava os princípios nacionalistas e autoritários do Estado Novo e os seus interesses imperiais extraeuropeus. Desde a sua origem, que o Portugal autoritário se distanciou da criação política e institucional do processo de integração europeia $^{31}$. Essa política de afastamento face à Europa Comunitária foi uma constante da política externa do Estado Novo salazarista. Nesse 
período, as principais imagens nacionais da política externa portuguesa foram constituídas por um importante triângulo identitário: o essencialismo, o ocidentalismo e o especialismo.

A imagem essencialista significava que as elites do Estado Novo assumiam o império como a essência, missão e finalidade histórica de Portugal no mundo. Construiu-se uma ideologia e cultura política entre as elites do Estado Novo que defendiam que, sem império, Portugal faleceria como entidade histórica. Não é possível compreender a política externa do Estado Novo sem assumir a importância que o império desempenhava na sua construção identitária. Tudo o que implicasse prejuízos à opção imperial era menorizado ou pura e simplesmente rejeitado.

A preservação do império dava ao Estado Novo o seu sentido de existência e a sua principal identidade (nacional e internacional). Para as elites do Estado Novo, o especialismo imperial português legitimava a sua razão de ser e dava sentido ao papel de Portugal no mundo: um Estado, em termos comparativos, importante, e não apenas um pequeno e relativamente irrelevante poder internacional. Perder o império era perder a sua identidade ontológica e a sua relevância internacional. Significava aniquilar a posição de Portugal na ordem internacional. Foi também essa ansiedade, neoedipiana, que limitou a capacidade de adaptação pós-imperial das elites portuguesas do Estado Novo.

A imagem do ocidentalismo significava a assunção de uma identidade cultural e civilizacional ocidental e cristã, bem como uma identidade política e geopolítica anticomunista que definiu o posicionamento de Portugal na lógica bipolar da Guerra Fria. A relação de Portugal com a Europa é enquadrada nessa imagem ocidentalista que significava, por um lado, a integração identitária de Portugal no espaço civilizacional da Europa Ocidental e, por outro, a integração geopolítica de Portugal no bloco ocidental, cristão e anticomunista, cuja expressão máxima foi a participação portuguesa na OTAN, mas que também se exprimiu na ONU.

A imagem do especialismo português dizia respeito ao conjunto de ideias e práticas políticas que argumentavam que Portugal era um caso especial. O especialismo português teve três dimensões: a histórica, a antropológica e a geopolítica. Historicamente, Portugal era um caso especial de invulgar expansão global que se iniciou com o movimento 
das Descobertas e de onde surgiram as primeiras tentativas de globalização político-diplomática. Antropologicamente, Portugal era especial devido à sua particular capacidade de diálogo intercultural e de desenvolvimento de uma política de miscigenação, de que resultou uma relativamente específica aptidão para criar sociedades multiculturais e multirraciais. Finalmente, Portugal era especial porque usufruía de uma situação geopolítica particular no Atlântico, especialmente no seu flanco sul, e por conjugar interesses na Europa, África e Ásia.

Foi esse triângulo identitário que construiu socialmente as ideias e práticas da política externa do Estado Novo e legitimou a doutrina de resistência imperial. Essa doutrina defendia que Portugal deveria resistir às pressões descolonizadoras e insistir na sua razão imperial-essencialista, legitimada pelo seu especialismo lusotropical e pela luta do ocidentalismo anticomunista que também se travava na África.

Existiu uma relação evidente entre as ideias, cultura política, imagens nacionais e percepções dos decisores do regime autoritário português e a definição dos interesses e opções de política externa do Estado Novo. Como se comprova, é a construção ideacional e intersubjetiva das imagens aqui identificadas que explica as opções da política externa do Estado Novo. Na sua origem ontológica, são as ideias, inexoravelmente interrelacionadas com os interesses, que constroem as identidades e imagens nacionais que vão formatar e delimitar as opções dos decisores.

Numa postura nacionalista, a política externa do Estado Novo assumiu um especialismo português que glorificava o papel histórico de Portugal. Com a sua ambição de restaurar o prestígio nacional e reconstruir uma nova ordem interna, a cultura política do Estado Novo usou a história para construir uma imagem nacional sobre um papel especial - importante e não decadente - de Portugal no mundo.

É inegável a resiliência de Portugal e a invulgar capacidade de resistência da sua política externa nesse período. Ao contrário de outros regimes autoritários fascistizantes europeus, o Estado Novo não sucumbiu com os movimentos políticos pós-autoritários da nova ordem internacional, pós-1945, e construiu uma forte e especial identidade autoritária. Essa identidade se desenvolveu através de um interessante processo de historicização heroica sobre o papel de Portugal no mundo. 
Podemos dizer, porém, que o Estado Novo foi vítima da sua excessiva historicização. É natural e importante que os Estados utilizem a história, os seus heróis, mitos e períodos áureos, para solidificarem a identidade do Estado e legitimarem as imagens da sua política externa. Todavia, existe um equilíbrio virtuoso entre o peso da história e a capacidade de adaptação face às mudanças e desafios constantes da política internacional. No caso do Estado Novo português, sobretudo a partir da década de 1960, foi evidente a sua incapacidade de adaptação pós-imperial e a consequente fossilização das ideias e imagens nacionais da sua política externa.

(Recebido para publicação em 24 de março de 2019)

(Reapresentado em 21 de junho de 2019)

(Aprovado para publicação em 29 de julho de 2019)

\section{NOTAS}

1. A imagem é um conceito originalmente inventado por Boulding $(1956,1959)$. O seu argumento principal é que, em última análise, o que é decisivo nas relações internacionais são as imagens nacionais que os líderes têm dos seus Estados, bem como as imagens internacionais que têm do funcionamento do sistema internacional. A imagem foi aplicada em várias áreas das ciências sociais, com destaque para as Relações Internacionais (Herrmann, 2013).

2. Existiam exceções à regra. Elites com formação mais tecnocrática que nos organismos públicos, ou na Associação Industrial Portuguesa, não eram antieuropeístas e que, sobretudo após a concretização da Comunidade Econômica Europeia (CEE) (1957), assumiam, prudentemente, a necessidade de Portugal se aproximar à Europa. Exemplo desta posição é visível em (MNE, 1957). Para uma visão sobre o debate posterior entre europeístas e imperialistas durante o marcelismo, veja-se: Mendes (2012, 2013, 2020b, 2020c) e Castilho (2000).

3. O que designamos por imagem essencialista de Portugal é inspirado na leitura do Ato Colonial, nomeadamente o seu art. nº 2, em que se afirma: "é da essência da nação portuguesa desempenhar a função histórica de possuir e colonizar domínios ultramarinos e de civilizar as populações indígenas que nelas se compreendam" (Mendes, 2012; ênfases nossas).

4. Esta visão tinha um lastro histórico que foi muito marcado pelo trauma da negação do Mapa Cor de Rosa Português na Conferência de Berlim, nas manobras diplomáticas das potências europeias continentais e na consequência final do Ultimatum Britânico. Neste quadro, Marcelo Caetano, também concorda que existiu sempre uma constante na política externa portuguesa: "Portugal é afectado ou ameaçado nos seus interesses ultramarinos sempre que se imiscuiu ou é envolvido nas questões internas do Continente europeu" (Caetano, 1971:128), cf. a nota 7 deste artigo.

5. Esta ideia é inspirada nas ideias e práticas da política externa portuguesas contidas em Nogueira (1984). Aqui a ideia não é considerada num tom apologético. 
6. Todavia, apesar da posição crítica de Kennedy em 1961, como sublinha Maxwell (2005:8) "durante a década de 1963-1973, nem a União Soviética nem os Estados Unidos forçaram grandes mudanças no status quo", cf. a nota 19 deste artigo.

7. No seu trabalho histórico-jurídico sobre a "internacionalização" do "ultramar português" Marcelo Caetano (1971) explica o histórico de "ataques", "golpes" e "cobiças" aos interesses ultramarinos de Portugal e as suas consequentes respostas político-jurídicas: desde a de Serafim de Freitas que, no seu De justo imperio lusitanoruam asiático de 1625, refuta a tese do holandês Grocio sobre o Mare Liberum, até ao século XX. Esta tradição político-jurídica interliga-se com o trauma histórico das batalhas perdidas por Portugal, veja-se mais à frente a nota 22 e o seu contexto.

8. Importa referir que esta viagem foi uma empreitada luso-espanhola, Magalhães, que era português, foi seu líder, mas ela foi finalmente realizada ao serviço da coroa espanhola. Magalhães morreu durante a viagem, que foi concluída pelo espanhol Juan Sebastián Elcano.

9. Como Ribeiro (2002) salienta, o regime salazarista construiu uma narrativa política que assumia que o Estado Novo era o herdeiro legítimo da missão civilizadora personificada pelos heróis portugueses dos descobrimentos, como o infante D. Henrique ou Vasco da Gama.

10. A fusão entre o nacionalismo e o colonialismo, a transcendência da nação e do império e a ideia da restauração do gênio nacional português (Monteiro e Pinto, 2000, 2011), não foram exclusivas ou originais do Estado Novo, mas só com o Salazarismo é que foram ideias e práticas da governança e a base de um discurso identitário nacional com as características aqui identificadas.

11. Militar e dirigente do Estado Novo. Foi Inspetor Superior da Administração Colonial e realizou um relatório sobre África (1947), no qual faz críticas ao "Colonialismo do Terreiro do Paço" (FMS). Em 1951, apoiou um candidato da oposição à Presidência da República, iniciando a sua dissidência com o Estado Novo. Em 1952, foi preso, exonerado do exército e condenado à prisão, da qual fugiu, em 1959, tendo-se exilado na Venezuela e depois no Brasil.

12. Os anos iniciais do Estado Novo são particularmente indicativos da ideia de restauração do gênio nacional e da celebração da missão imperial. As exposições coloniais no Porto (1934) e em Lisboa (1940), comprovam que uma das ideias principais da aceitação do novo regime foi a da regeneração da missão imperial de Portugal.

13. Como demonstra Santos (2002), a especificidade do colonialismo português também não pode ser desligada da condição semiperiférica de Portugal e da consequente construção de um "colonialismo subalterno".

14. Embora não eliminando completamente a idealização lusotropical de miscigenação, importa sublinhar que existia uma evidente diferenciação - social, econômica e política - entre "brancos" e "negros" no império português e persistiam práticas racistas e discriminatórias que ainda traduziam as raízes históricas do tráfico de escravos. Todavia, após a necessidade de justificar o especialismo multirracial e lusotropical português, existiu um esforço de adotar práticas e discursos de tolerância racial.

15. Freyre sublinhou a capacidade portuguesa de desenvolver a mestiçagem e a interpenetração cultural, em razão das próprias origens portuguesas serem influenciadas 
por cruzamentos culturais e civilizacionais. As suas ideias iniciais (1930 e 1940), não tiveram muita atenção do Estado Novo. Em 1958, Freyre publica um livro apologético da multiculturalidade racial lusotropical. Este livro, Integração portuguesa nos trópicos, foi financiado pelo Estado Novo e utilizado pela propaganda portuguesa. Em 1961, sai uma edição em inglês para circulação internacional, nomeadamente pelas missões diplomáticas portuguesas.

16. Em várias áreas, foi visível a inspiração lusotropical, por exemplo, na Geografia (Orlando Ribeiro), na Agronomia (Henrique de Barros), no Direito Público e Ciência Política (Marcelo Caetano e Adriano Moreira), na Antropologia (Jorge Dias), Filosofia (António Quadros) e História da Arte (Mário Chico). Com Adriano Moreira no Ministério do Ultramar, promulgaram-se vários pacotes legislativos influenciados pelo lusotropicalismo (Castelo, 1988).

17. Convém, contudo, sublinhar que o lusotropicalismo de Freyre teve várias e por vezes contraditórias recepções das elites do Estado Novo. Existiam ideias de Freyre que chocavam com o conservadorismo do Estado Novo dos anos 1930 e 1940, nomeadamente a visão tolerante e otimista da mestiçagem, que contrastava com a visão oficial e majoritária das elites da superioridade racial e civilizacional branca face aos incivilizados africanos (Castelo, 2019). Mesmo na década de 1970, quando o lusotropicalismo foi apropriado pelo Estado Novo, foi-o sempre seletivamente, demonstrando a regra geral de normalização parcimoniosa que sempre acontece quando o pensamento intelectual se aproxima ou é apropriado pelo poder governamental. Por outro lado, importa recordar a transversalidade ideológica das elites portuguesas relativamente à socialização simbólica e ideológica sobre a "finalidade histórica" de Portugal se refletir na sua missão imperial. (Alexandre, 1993a, 1993b, 2000, 2011).

18. Mesmo nas questões militares existia um componente ideológica e doutrinária. Por exemplo, nas conferências do Instituto de Altos Estudos Militares, estão presentes alguns dos teóricos do regime - Marcello Caetano e Adriano Moreira - bem como, Arnold Toynbee, que fala sobre o "Ocidente e o Futuro", demonstrando, novamente, a importância das ideias do ocidentalismo e do seu aproveitamento político (IAEM, 1960).

19. Portugal tinha o controle geo-estratégico do importante triângulo atlântico, Lisboa-Açores-Madeira, e usufruía de vantagens estratégicas em várias rotas triangulares (Lisboa-Washington-Guiné, etc.) do Atlântico Sul e do "mar luso-brasileiro".

20. Apesar da posição crítica da Administração Kennedy e de algum desconforto na OTAN, Portugal teve, quase sempre, o apoio dos seus aliados ocidentais, particularmente dos membros permanentes no Conselho de Segurança da ONU (Maxwell, 1985; Silva, 1995; MacQueen, 1998; Martins, 1998; Rodrigues, 2002; Pinto e Lloyd-Jones, 2003; Rosas, Machaqueiro e Oliveira, 2015).

21. O ano de 1960 iniciou a viragem da ordem normativa na ONU relativamente à descolonização e o ano de 1961 foi um annus horribilis para o Estado Novo. Em 1961, Kennedy e Jânio Quadros, chegam ao poder e acentuam o isolamento diplomático português. Sucedem-se: o assalto do paquete Santa Maria; o início dos ataques do Movimento Popular de Libertação de Angola (MPLA) e da União das Populações do Norte de Angola (UPA) em Angola; a tentativa de golpe do general Botelho Moniz; e a invasão de Goa pela Índia.

22. Nogueira sempre defendeu a intransigência da política imperial: "'todas as transigências, todos os apaziguamentos', jogariam por força contra Portugal, pois nunca conseguiriam 
aplacar os seus inimigos, «nunca seriam satisfatórios nem finais" (Apud Lucena, 2001: 878). Após deixar de ser ministro, como deputado (1970), Nogueira continuou a sua luta em defesa da integridade da "Nação Portuguesa na sua totalidade", leia-se império (Mendes, 2013).

23. Para além de ter sido o primeiro império colonial da Era Moderna, Portugal foi o Estado que sofreu mais perdas para os seus rivais. Portugal foi vítima dos impérios britânico, francês e holandês. Este trauma histórico teve como marco o ultimato britânico (Teixeira, 1990, 2011) e influenciou as ideias e percepções das elites decisoras da política externa até ao século XX (Caetano, 1971).

24. Embora num contexto diferente, por exemplo, a França conseguiu integrar a Guiana Francesa no seu território e na CEE.

25. Como membro fundador de plenos direitos seria difícil, mas poderia ter feito, logo em 1957, um acordo de associação e provavelmente ter pedido a adesão dez anos depois.

26. Para vários exemplos excepcionais da cultura de tolerância racial e cultural do império Português, na visão oficial do Estado Novo, veja-se: Carvalho (1964:48-50). Para uma visão não oficial e mais próxima da realidade histórica, veja-se: Santos (2002). Para uma visão global e comparada, veja-se: Bethencourt (2015).

27. Como aponta Alexandre (1993b, 2011), a negação da visão colonial de Norton de Matos e a aplicação do modelo colonial centralista e protecionista do Ato Colonial, defendido por Salazar e pelas elites econômicas portuguesas, esteve na origem das dificuldades da construção de um modelo descentralizador, autonômico e desenvolvimentista nas colônias portuguesas.

28. Como em certo sentido, mas não exclusivamente, aconteceu com a resposta ao problema de Goa.

29. Franco Nogueira foi um diplomata de carreira e ministro dos Negócios Estrangeiros, entre 1961-1969. Foi, a par de Salazar, o principal ideólogo e decisor da política externa de resistência imperial. Foi um político intelectual que escreveu várias obras importantes sobre o período salazarista e o seu essencialismo (cf. Lucena, 2001).

30. Isto é importante para percebermos melhor como e porquê Estados com identidades diferentes do mainstream moderno-ocidental funcionam e decidem as suas opções de política externa. Por outro lado, é recorrente constatar-se a insensibilidade histórica de analistas e decisores das elites internacionais ocidentais na compreensão do peso da história e das identidades na construção social das políticas e doutrinas da política externa de Estados. Finalmente, importa ter consciência da importância da lógica identitária nas atuais reconstruções ideológicas ligadas aos processos de retrocesso democrático e ascensão populista.

31. Portugal esteve institucionalmente envolvido com organizações europeias e ocidentais, mas de cariz tecnocrático e comercial - como a Organização para a Cooperação e Desenvolvimento Econômico (OCDE) (1948) ou a Associação Europeia de Comércio Livre (EFTA) (1960) -, que não exigiam nenhuma condição político-democrática, nem implicavam nenhum movimento de integração supranacional. Esta opção da política externa portuguesa foi claramente expressa por Salazar na sua "Circular enviada às embaixadas e delegações de Portugal" em 1953. 


\section{REFERÊNCIAS BIBLIOGRÁFICAS}

ALEXANDRE, Valentim. (1993a), Os sentidos do Império. Questão nacional e questão colonial na crise do Antigo Regime Português. Porto: Afrontamento.

. (1993b), "Ideologia, economia e política: a questão colonial na implantação do Estado Novo". Análise Social, n. 123/124, pp. 1117-1136.

. (2000), O Império Africano Séculos XIX e XX. Lisboa: Edições Colibri.

. (2011), "The Colonial Empire". In: A. C. Pinto (ed.), Contemporary Portugal: politics, society and culture. 2. ed. New York: SSM, Columbia University Press, pp. 73-94.

BETHENCOURT, Francisco. (2015), Racisms: from the crusades to the twentieth century. Princeton: PUP.

BOULDING, Kenneth. (1956), The Image: knowledge in life and society. Ann Arbor: UMP.

. (1959), "National images and international systems". The Journal of Conflict Resolution. v. 2, n. 3, pp. 120-131.

CAETANO, Marcello. (1971), Portugal e internacionalização dos problemas africanos. $4^{\mathrm{a}}$ ed. Amadora: Bertrand.

CARVALHO, Henrique Martins de (1964), "Política externa portuguesa". Estudos de Ciências Sociais e Políticas, n. 70. Lisboa: Junta de Investigações do Ultramar.

CASTELO, Cláudia. (1998), O modo português de estar no mundo: o lusotropicalismo e a ideologia colonial portuguesa. Porto: Edições Afrontamento.

. (2019), "Gilberto Freyre's view of miscegenation and its circulation in the Portuguese empire (1930s-1960s)". In: W. Anderson; R. Roque; R. V. Santos (eds.), Lusotropicalism and Its Discontents: the making and unmaking of racial exceptionalism. New York: Berghahnbooks.

CASTILHO, José Manoel T. (2000), A ideia da Europa no Marcelismo (1968-1974). Lisboa: AR, Afrontamento.

CHECKEL, Jeffrey T. (2008), “Constructivism and Foreign Policy”. In: S. Smith; A. Hadfield; T. Dunne (eds.), Foreign Policy: Theories. Actors. Cases. Oxford: OUP, pp. 74-75.

FERREIRA, José M. (1993), “Características históricas da Política Externa portuguesa entre 1890 e a entrada na ONU”. Política Internacional. v. 6, n. 1, pp. 113-156.

FREYRE, Gilberto. (1940), O mundo que o português criou: aspectos das relações sociais e de cultura do Brasil com Portugal e as colônias portuguesas (pref. António Sérgio). Lisboa: Livros do Brasil.

. (1958), Integração portuguesa nos trópicos. Lisboa: Junta de Investigações do Ultramar. . (1961), Portuguese Integration in the Tropics. Lisboa: Agência Geral do Ultramar.

GALVÃO, Henrique. (1930), A Nacionalização de Angola. Conferência na Sociedade de Geografia de Lisboa. Lisboa, ed. Autor.

HERRMANN, Richard K. (2013), "Perceptions and image theory in international relations". In: H., Leonie; D. O. Sears; J. S. Levy (eds.). The Oxford Handbook of Political Psychology. (2 ed.). New York: OUP. 
HOLSTI, Ole. (1962), "The belief system and national images: a case study". Journal of Conflict Resolution, v. 6, pp. 244-252.

HOUGHTON, David P. (2007), "Reinvigorating the study of foreign policy decision-making: toward a constructivist approach". Foreign Policy Analysis, v. 3, n. 1, pp. 24-45.

JERVIS, Robert. (2017), Perception and misperception in international politics. New edition, New Jersey: PUP.

KATZENSTEIN, Peter (ed.) (1996), The Culture of National Security. New York: CUP.

KOWERT, Paul A. (2010), "Foreign policy and the social construction of state identity". In: R. Marlin-Bennett; A. Denemark. (eds.). The International Studies Encyclopedia. Oxford: Blackwell Publishing.

KUBALKOVA, Vendulka (ed.). (2001), Foreign policy in a constructed world. Armonk, NY: M. E. Sharpe.

LÉONARD, Yves. (1997), "Salazarisme et lusotropicalisme, histoire d'une appropriation". Lusotopie. pp. 211-226.

LUCENA, Manuel de. (2001), "Franco Nogueira: os meandros de uma fidelidade". Análise Social, v. XXXVI, n. 106, pp. 863-891.

MACQUEEN, Norrie. (1998), A descolonização da África portuguesa. Mem Martins: Inquérito.

MAGALHÃES, José Calvet. (1987-1988), “Portugal e a integração europeia”. Estratégia. v. 4 , pp. 33-74.

MARTINS, Fernando. (1998), "A política externa do Estado Novo, o ultramar e a ONU”. Penélope. n. 18, pp. 189-206.

MAXWELL, Kenneth. (1985), "As Colônias portuguesas e a sua descolonização”. Revista Crítica de Ciências Sociais, n. 15/16/17, pp. 529-547.

. (2005), “Os Estados Unidos e a descolonização portuguesa (1974-1976)". Relações Internacionais, n. 8, pp. 54-38.

MELO, Manuel Homem de. (1965), "Política Externa portuguesa na Europa e no Ultramar". In: Separata do Boletim de Informação. n. 10. Lisboa.

MENDES, Pedro Emanuel. (2012), Portugal e a Europa: Factores de afastamento e aproximação da Política Externa portuguesa (1970-1978). Porto: CEPESE.

. (2013), "A questão europeia no marcelismo: o debate geracional". População e Sociedade, n. 21, pp. 107-121.

. (2016), "Identidade e poder na Política Externa da Indonésia: De Sukarno a Suharto". Relações Internacionais, n. 52, pp. 67-82.

. (2017a), "O poder e as ideias na política externa da Indonésia democrática: ser ou não ser um ator global?". Relações Internacionais, n. 55, pp. 71-98.

. (2017b), "Como compreender e estudar a decisão em política externa: reinterpretando os clássicos". Brazilian Journal of International Relations, v. 6, n. 1, pp. 8-36.

. (2018), "Identidade, ideias e normas na construção dos interesses em política externa: o caso português". Análise Social, v. LIII, n. 227, pp. 458-487.

DADOS, Rio de Janeiro, vol.63(3): e20190067, 2020. 
. (2020a), "R(r)elações I(i)nternacionais, realismo e análise da Política Externa (APE): contextualizando a invenção da APE”. Estudos Internacionais, v. 8, n. 1, pp. 64-88.

. (2020b), "Marcelo Caetano". In: F. Sousa; C. Meireles (eds.), Os Primeiros Ministros de Portugal. Lisboa: INCM.

. (2020c), "Os dilemas da renovação na continuidade e o legado de Marcello Caetano: do outono ao inverno". Tempo e Argumento, v. 12, n. 29, e0205.

MODELSKI, George. (2000), “World System Evolution”. In: R. Denemark et al. (eds.), World System History. New York: Routledge.

MONTEIRO, Nuno G.; PINTO, António C. (2000), "Mitos culturais e identidade nacional portuguesa". In: A. C. Pinto (ed.), Portugal Contemporâneo. Madrid: Sequitur, pp. 232-245.

. (2011), "Cultural Myths and Portuguese National Identity". In: Pinto, A. C. Contemporary Portugal: Politics, Society and Culture. 2nd ed. New York, SSM: CUP, pp. 55-72.

MOREIRA, Adriano. (1955a), Imperialismo e colonialismo da União Indiana. Lisboa: Agência Geral do Ultramar.

. (1955b), "A conferência de Bandung e a missão de Portugal". Separata do Boletim da Sociedade de Geografia. Lisboa: SGL, pp. 5-25.

. (1956), Política ultramarina. Lisboa: Junta de Investigações do Ultramar.

. (1957), "Portugal e o artigo 73 da Carta das Nações Unidas". Separata da Revista do Gabinete de Estudos Ultramarinos, n. 5, pp. 1-134.

. (1966), "As novas fronteiras e o direito à imagem nacional". Estudos Políticos e Sociais, v. 1, n. IV, pp. 5-18.

NOGUEIRA, F. (1967), Terceiro Mundo. Lisboa: Ed. Ática.

(1970), Debate Singular. Lisboa: Ed. Ática.

. (1979a), Diálogos interditos: a Política Externa portuguesa e a Guerra de África, I vol. Braga/ Lisboa: Editorial Intervenção.

. (1979b), Diálogos interditos: a Política Externa portuguesa e a Guerra de África, II vol. Braga/Lisboa: Editorial Intervenção.

. (1980), Salazar, V. 4. O ataque (1945-1958). Porto: Civilização.

. (1984), Salazar, V. 5. A resistência (1958-1964). Porto: Civilização.

. (1985), Salazar, V. 6. O último combate (1964-1970). Porto: Civilização.

ONUF, N. (2013), Making Sense, Making Worlds: Constructivism in Social Theory and International Relations. London/New York: Routledge.

PINTO, António C.; LLOYD-JONES, S. (eds.). (2003), The last empire. Thirty years of portuguese decolonization. Bristol: Intellect.

RIBEIRO, Margarida C. (2002), "Empire, Colonial Wars and Post-Colonialism in the Contemporary Portuguese Imagination". Portuguese Studies Review. v. 18, pp. 132-214.

ROLLO, Maria Fernanda. (1998), "Salazar e a construção europeia”. Penélope, n. 18, pp. 51-76. 
Pedro Emanuel Mendes

RODRIGUES, Luís N. (2002), Kennedy-Salazar: A crise de uma aliança. As relações luso-americanas entre 1961 e 1963. Lisboa: Editorial Notícias.

SALAZAR, António O. (1951), Discursos e notas politicas IV (1943 a 1950). Coimbra: Coimbra Editora.

. (1959), Discursos e notas políticas V, (1951 a 1958). Coimbra: Coimbra Editora.

. (1963), Declaração sobre Política Ultramarina. Lisboa: Secretaria Nacional da Informação.

SANTOS, Boaventura de S. (2002), "Between Prospero and Caliban: Colonialism, Postcolonialism, and Inter-identity". Luso-Brazilian Review, n. 39, pp. 9-43.

SCHAFER, Mark; WALKER, Stephen G. (2006), Beliefs and Leadership in World Politics. New York: Palgrave.

SILVA, A. R. (1964), Política Ultramarina portuguesa, seus objectivos históricos e actuais, sua posição perante a conjuntura internacional. Instituto dos Altos Estudos Militares. Lisboa: Agência Geral do Ultramar.

TEIXEIRA, Nuno S. (1990), O Ultimatum Inglês. Política externa e política Interna no Portugal de 1890. Lisboa: Alfa.

. (2011), "Between Africa and Europe: Portuguese Foreign Policy". In: A. C. Pinto (ed.), Contemporary Portugal: Politics, Society and Culture. New York: CUP, pp. 73-95.

TELO, António José. (1995), “Portugal e a NATO: dos Pirenéus a Angola”. In: Análise Social. v. 134, n. 5 , pp. $947-973$.

TETLOCK, P.E. (1999), “Theory-Driven Reasoning about Possible Pasts and Probable Futures: Are We Prisoners of Our Preconceptions?". In: American Journal of Political Science. vol. 43, pp. 335-366.

ROSAS, F.; Machaqueiro, M.; Oliveira, P. A. (orgs). (2015), O adeus ao Império. 40 anos de descolonização portuguesa. Lisboa: Nova Vega.

THEMIDO, João Hall. (1960), "Portugal e o anticolonialismo". Estudos de Ciências Sociais e Políticas, n. 29. Lisboa: Junta de Investigações do Ultramar.

\section{FONTES PRIMÁRIAS}

MNE (Ministério dos Negócios Estrangeiros). PC. Entrevista do Ministro dos Negócios Estrangeiros, Prof. Paulo Cunha, ao Diplomatische Korrespondenz, visita a Bona. Arquivo Histórico-Diplomático, AHD - PEA 2. ${ }^{\circ}$ P, M 309.

. (1953), "Confidencial Política de Federação Europeia", Oliveira Salazar. Circular enviada às embaixadas e delegações de Portugal, 6 de março de 1953. Arquivo Histórico-Diplomático, AHD-PEA M. 309.

. (1957), Relatório da Comissão Encarregada do Estudo dos Problemas relativos à Criação e Funcionamento da Zona de Comércio Livre (no âmbito da OECE), 28 de Janeiro de 1957. Arquivo Histórico-Diplomático, AHD - PEA 2. ${ }^{\circ}$ P, A. 6, M. 439.

. (1970), Portugal Replies in the United Nations. Lisboa: INCM.

DADOS, Rio de Janeiro, vol.63(3): e20190067, 2020. 
FMS (Fundação Mário Soares). Rapport Galvão I. Documents - Relatório Henrique Galvão. 22 de janeiro de 1947. Fundação Mário Soares (FMS), Fundo de documentos Mário de Andrade.

IAEM (Instituto de Altos Estudos Militares). (1960), Conferências proferidas em 1959/60. 1 vol. Instituto de Altos Estudos Militares. Caxias: Instituto de Altos Estudos Militares. 


\section{RESUMO}

Percepções e Imagens na Política Externa do Estado Novo Português: A Importância do Triângulo Identitário

Este artigo analisa as percepções e imagens nacionais da política externa portuguesa durante o Estado Novo salazarista. Traça um enquadramento do contexto ideacional da política externa portuguesa desde o Pós-Guerra até a década de 1960 e explica o posicionamento de Portugal face a dois desafios internacionais: o projeto de integração europeia e o movimento descolonizador. $\mathrm{O}$ artigo tem por base pesquisa documental de fontes primárias e secundárias relativas às ideias e discursos das elites da política externa portuguesa. $\mathrm{O}$ artigo demonstra duas ideias-chave. Primeiro, as opções e doutrinas de política externa devem ser lidas tendo em consideração a sua historicidade e as percepções e imagens dos seus decisores. Segundo, a política externa é uma política de identidade e as imagens nacionais que os Estados historicamente constroem para legitimarem os seus interesses não podem ser desligadas dos processos de imaginação identitária e de afirmação de uma determinada cultura política nacional. O artigo apresenta uma teorização ideacional e identitária sobre as razões das opções antieuropeísta e antidescolonizadora da política externa do Estado Novo. O seu principal argumento é que uma análise sofisticada da política externa portuguesa nesse período deve fazer apelo ao que designamos de triângulo identitário: essencialismo, especialismo e ocidentalismo.

Palavras-chave: Estado Novo (Portugal); política externa; imagens nacionais; identidade; elites autoritárias

\section{ABSTRACT \\ Perceptions and Images in the Foreign Policy of the Portuguese "Estado Novo Português" [New State Portuguese]: The Importance of the Identity Triangle}

This article analyzes the national perceptions and images of the Portuguese foreign policy during Salazar's Estado Novo [New State]. We have framed the ideational context of the Portuguese foreign policies from the Post-War until the 1960s and explained Portugal's position in the face of two international challenges: the European integration project and the decolonizing movement. The article is based on documentary research from primary and secondary sources related to the ideas and discourses of Portuguese foreign policy elites. The article addresses two key ideas. Firstly, foreign policy actions and doctrines must be understood taking into account their historicity and the perceptions and images of their decision-makers. Secondly, foreign policy is an identity policy, that is, the national images that States historically build to legitimize their interests cannot be disconnected from the 
processes of identity imagination and affirmation of a particular national political culture. This article presents an ideational and identity theorization about the reasons for the anti-Europeanist and anti-colonialist postures of the Estado Novo's foreign policy. The main argument is that a sophisticated analysis of Portuguese foreign policy in this period must start from what we call the identity triangle: essentialism, specialism, and westernism.

Keywords: Estado Novo (New State, Portugal); foreign policy; national images; identity; authoritarian elites

\section{RÉSUMÉ}

Perceptions et Images dans la Politique Étrangère de l'Estado Novo Português: L'Importance du Triangle Identitaire

Cet article analyse les perceptions nationales et les images de la politique étrangère portugaise lors de l'Estado Novo de Salazar. On décrit le contexte idéologique de la politique étrangère portugaise de l'après-guerre aux années 1960 et on explique la position du Portugal face à deux défis internationaux: le projet d'intégration européenne et le mouvement de décolonisation. L'article est basé sur la recherche documentaire de sources primaires et secondaires liées aux idées et aux discours des élites portugaises de politique étrangère. L'article présente deux idées-clés. Premièrement, les options et doctrines de politique étrangère doivent être lues en tenant compte de leur historique et des perceptions et images de leurs décideurs. Deuxièmement, la politique étrangère est une politique d'identité et les images nationales que les États ont historiquement construites pour légitimer leurs intérêts ne peuvent pas être déconnectées des processus d'imagination identitaire et d'affirmation d'une culture politique nationale particulière. L'article présente une théorisation idéationnelle et identitaire sur les raisons des options anti-européanistes et anticolonialistes de la politique étrangère de l'Estado Novo. Son principal argument est qu'une analyse sophistiquée de la politique étrangère portugaise de cette période doit faire appel à ce que nous appelons un triangle identitaire: l'essentialisme, la spécialisation et l'occidentalisme.

Mots-clés: Estado Novo (Portugal); politique étrangère; images nationales; identité; élites autoritaires 


\section{RESUMEN}

Percepciones e Imágenes en la Política Exterior del Estado Novo Português: La Importancia del Triángulo Identitario

Este artículo analiza las percepciones e imágenes nacionales de la política exterior portuguesa durante el Estado Novo salazarista. Traza un encuadramiento del contexto ideacional de la política exterior portuguesa desde la Posguerra hasta la década de 1960 y explica el posicionamiento de Portugal frente a dos desafíos internacionales: el proyecto de integración europea y el movimiento descolonizador. El artículo tiene como base la investigación documental de fuentes primarias y secundarias relativas a las ideas y discursos de las élites de la política exterior portuguesa. El artículo demuestra dos ideas clave. Primero, las opciones y doctrinas de política exterior deben ser leídas teniendo en cuenta su historicidad y las percepciones e imágenes de sus decisores. Segundo, la política externa es una política de identidad y las imágenes nacionales que los Estados históricamente construyen para legitimar sus intereses no pueden desligarse de los procesos de imaginación de la identidad y de afirmación de una determinada cultura política nacional. El artículo presenta una teorización ideacional e identitaria sobre las razones de las opciones antieuropeista y antidescolonizadora de la política exterior del Estado Novo. Su principal argumento es que un análisis sofisticado de la política exterior portuguesa en ese período debe apelar a lo que designamos de triángulo identitario: esencialismo, especialismo y occidentalismo.

Palabras clave: Estado Novo (Portugal); política exterior; imágenes nacionales; identidad; élites autoritarias 